\title{
CORTISONE AND SALICYLATES IN CHRONIC RELAPSING RHEUMATIC CARDITIS
}

\author{
BY \\ J. LORBER, K. S. HOLT, JOHN RENDLE-SHORT, AND R. S. ILLINGWORTH \\ Department of Child Health, University of Sheffield
}

In our two previous communications (Holt, Illingworth, Lorber, Rendle-Short, and Gibson, 1954; Illingworth, Lorber, Holt, Rendle-Short, Jowett, and Gibson, 1957) we have shown that cortisone combined with salicylates is an effective treatment for children suffering from rheumatic fever and that it is better than treatment with either cortisone or salicylates alone. In these publications we analysed the response to treatment in their initial attack, or in the case of subsequent attacks on the first occasion on which they came under our care. There was some evidence that the combined treatment was not quite as effective in long-standing rheumatic fever or in second or subsequent attacks. Of eight children who had symptoms of over 30 days' duration, only two lost their cardiac murmurs as a result of combined treatment, as compared with twenty out of thirty who were admitted within thirty days of the onset of symptoms. Furthermore, the erythrocyte sedimentation rates tended to fall more slowly in children in their second or subsequent attacks.

In this paper we shall describe the response to combined cortisone and salicylate treatment of six children, five girls and one boy, who had one or more previous attacks of rheumatic fever. In all cases there had been continuous rheumatic activity for several months before hormone treatment was instituted and all had gross cardiac damage.

\section{Present Investigation}

Five children (Cases 1-3, 5, and 6) were admitted to the Rheumatic Fever Hospital School after prolonged treatment in other hospitals, and one (Case 4) was admitted to the Children's Hospital. This girl had been included in her initial attack in a controlled study (Illingworth and others, 1957) and had been treated with salicylates in high dosage. Her subsequent attacks, in which she was treated with cortisone with salicylates, were not described in this previous paper. One of the six children (Case 5) had an acute exacerbation of her rheumatic fever soon after reaching the Rheumatic Fever Hospital School, and was therefore transferred to the Children's Hospital because she satisfied the criteria for inclusion in our controlled series. She was treated with cortisone and salicylates in low dosage, and her progress during this attack is incorporated in another paper (Illingworth and others, 1957). All the others were treated at the Rheumatic Fever Hospital School and have not been included in any previous series described by us. At the time when their treatment was started none of these satisfied the strict criteria for admission to our controlled series but all had undoubted active carditis.

All six children received cortisone or prednisolone in association with salicylates, either until three consecutive weekly normal erythrocyte sedimentation rates had been obtained or for longer periods if considered necessary.

As most of these children had no overt rheumatic manifestations such as fever or arthritis, we shall confine our analysis to their general condition, the condition of the heart, and the rate of fall of the erythrocyte sedimentation rate.

Taking relapses into account, these six children have received so far fourteen courses of combined treatment.

\section{Results}

Group 1. Good Response.-Three children, aged 9, 9, and 11 years (Cases 1-3), responded well to treatment with prednisolone combined with salicylates in low dosage. The erythrocyte sedimentation rate returned to normal in all three on the seventh day and in two remained normal for 5 and 8 weeks respectively until treatment was discontinued. In these two a short rebound followed, consisting of an elevation of the erythrocyte sedimentation rate for 2 weeks, and their subsequent progress was unevent- 
ful. In the third a rebound occurred when the dose of prednisolone was reduced to $5 \mathrm{mg}$. daily, but the erythrocyte sedimentation rate returned to normal without further change in dosage. In no case was there any significant change in the size of the heart or in the cardiac signs.

Case 1, a boy aged 11 years on admission, had had his first attack of rheumatic fever at the age of 6 and a second attack at the age of 7 , for which he was treated in another hospital with salicylates and Digoxin. He was found to have apical systolic and diastolic murmurs at that time.

His third attack started in October, 1955, at the age of 11, after a sore throat. He had polyarthritis, and 2 weeks after the onset was admitted to another hospital. At that time he had a rough apical systolic and a soft diastolic murmur. The erythrocyte sedimentation rate was $68 \mathrm{~mm}$./hr (micro Westergren). He was treated with'salicylates and oral penicillin for 3 months, after which he was transferred to the Ash House Rheumatic Fever School.

On admission on January 23, 1956, he was pale and thin. He had gross tachycardia and a bulging praecordium; the apex beat was in the fifth space in the midaxillary line and he had signs of a double mitral valve lesion and of aortic regurgitation (B.P.120/50). There was radiographic evidence of considerable enlargement of the heart in the transverse diameter. The heart was of the shape usually associated with combined mitral and aortic disease. The erythrocyte sedimentation rate was $26 \mathrm{~mm}$. $/ \mathrm{hr}$.

He was kept in bed without specific treatment for 32 weeks, during which time his general condition and cardiac signs did not alter, except that his aortic diastolic murmur was only heard intermittently. The erythrocyte sedimentation rate fell below $15 \mathrm{~mm}$./hr on only one occasion (Fig. 1).

Treatment was then begun with prednisolone and solprin. Before that the erythrocyte sedimentation rate had been $25 \mathrm{~mm}$./hr or more for 3 consecutive weeks, but it fell to normal by the seventh day and remained normal throughout his 8 weeks of treatment. The initial dose of prednisolone was $60 \mathrm{mg}$. and the dose was gradually reduced to $5 \mathrm{mg}$. daily. The dose of Solprin was 30 gr. $(2$ g.) daily. For 2 weeks after stopping treatment the erythrocyte sedimentation rate was 25 and $23 \mathrm{~mm}$./hr; it then fell to $3 \mathrm{~mm}$./hr and remained normal for 11 weeks, after which he was discharged home.

Case 2, a girl aged 9 years on admission, had her first attack of rheumatic fever when $6 \frac{1}{2}$ years old, and had carditis at that time. Salicylates in low doses were given in another hospital for 8 weeks with general improvement but no change in the heart signs; 10 weeks later she had a recurrence of rheumatic fever and was again treated with salicylates for 5 weeks with symptomatic improvement, but with no fall in the erythrocyte sedimentation rate and no change in the heart signs; 2 weeks later, while still in the same hospital, her condition relapsed again and treatment was started with prednisolone combined with salicylates in low dosage. The erythrocyte sedimentation rate became normal within 3 weeks.? Treatment was given for 7 weeks, and its cessation was $\overrightarrow{=}$ followed by a rise in the erythrocyte sedimentation rate, $\stackrel{\oplus}{+}$ although she was well in herself at this time. There was? a coarse grade 4 systolic murmur at the apex of the heart.음

She was transferred to the Rheumatic Fever Hospitalos School on October 12, 1956. She was well in herself $\mathbb{Q}$ but during $3 \frac{1}{2}$ months of observation the erythrocyte sedimentation rate was persistently raised, ranging from ${ }^{\circ}$ 12 to $43 \mathrm{~mm}$./ $\mathrm{hr}$. In this period several carious teeth $\vec{\circ}$ were removed without effect on the clinical course.

Treatment was then started with prednisolone com- $\vec{\omega}$ bined with salicylates in low doses. The sedimentation rate, which was $25 \mathrm{~mm}$./hr just before the start of therapy, became normal within a week, and remained so for. 4 weeks, but when the dose of prednisolone was reduced to $5 \mathrm{mg}$. daily there was a rebound of the erythrocyte sedimentation rate to $21 \mathrm{~mm}$./hr. This graduallyoo returned to normal within 3 weeks without any alteration in the treatment. There was no change in the heart signs 5 during this time. Her general condition, however, $\overrightarrow{-}$ improved greatly during this course of treatment.

Group 2. Good Response with Relapses.-The response to treatment in two other children (Cases $4 \stackrel{\mathbb{D}}{-}$ and 5) aged 11 and 13 was very similar to that $8 f_{\vec{c}}$ Cases $1-3$, except that shortly after discontinuation of treatment they both relapsed and relapses co tinued to occur up to the time of writing, wheno Case 4 was on her sixth and Case 5 on her fourth course of treatment. The response to treatmento remained satisfactory during each course in Case $4, \stackrel{\circ}{\mathbb{Q}}$ yet a relapse occurred on withdrawal after treatment $\stackrel{\circ}{\rightarrow}$ had been continued for as long as 16 weeks with aô normal erythrocyte sedimentation rate. In Case 5,3 the erythrocyte sedimentation rate fell more slowly? to normal during each course ( 21 to 42 days) and in:only two of the four courses was a sequence of three normal weekly erythrocyte sedimentation rates attained. In the last course the erythrocyte sedi-3. mentation rate again became abnormal duringo treatment, which is now in its seventh month.

Case 5, a girl aged 13 years on admission, had haळำ chorea when 7 years old; and when 13 years old (in February, 1955) she had been admitted to another hospital with acute rheumatic fever. She had a largen heart, pericarditis, and heart failure. She was treated with digoxin and salicylates in low dosage with some improvement, but the erythrocyte sedimentation ratê remained high.

She was transferred to the Rheumatic Fever Hospitak School in August, 1955. She had a large heart with double mitral lesion and aortic incompetence. The erythrocyte sedimentation rate was $50 \mathrm{~mm}$./hr. Shortly.after admission she developed an acute polyarthritis and was transferred to the Sheffield Children's Hospital for treatment with cortisone and salicylates in high doses. 
Her general condition improved and the erythrocyte sedimentation rate became normal within 21 days, and remained so until treatment was stopped after 42 days, when there was a prompt relapse with fever and a high erythrocyte sedimentation rate.

A second course of treatment was given, consisting of prednisolone and salicylates in high dosage. The erythrocyte sedimentation rate became normal within 21 days, but throughout the remainder of the 81 days of therapy it fluctuated between 10 and $20 \mathrm{~mm}$. $/ \mathrm{hr}$. When treatment was stopped the erythrocyte sedimentation rate again rose and remained high for 4 weeks. The third course of treatment was then commenced, this time with prednisolone and salicylates in low dosage. The erythrocyte sedimentation rate fell to normal within 21 days but fluctuated between 10 and $30 \mathrm{~mm}$./ $/ \mathrm{hr}$ throughout the $8 \frac{1}{2}$ months that treatment was pursued.

Relapse followed the end of the third course of therapy, so that after 3 weeks, a fourth course was started with prednisolone and salicylates in high dosage. This time the erythrocyte sedimentation rate did not fall to normal until the 42nd day, but it then remained normal for 5 weeks. At this stage salicylates were stopped and prednisolone was continued alone. The erythrocyte sedimentation rate promptly rose to $35 \mathrm{~mm}$./ $\mathrm{hr}$ and has not returned to normal since, in spite of the re-introduction of salicylates. There was no appreciable change in the heart during all this time in hospital.

Group 3. Poor Response.-One child did not respond to treatment adequately.

Case 6, a girl aged 13 years on admission, had a normal erythrocyte sedimentation rate within 14 days of starting treatment with cortisone and salicylates in low dosage, but thereafter the rate consistently raised. This girl had haematemesis as a complication of treatment. The case is described more fully elsewhere (Lorber, 1957).

The response of these chronic relapsing cases to combined cortisone and salicylate therapy is summarized in the Table.

Three (Group 1) responded promptly to therapy and have not had further trouble.

Two (Group 2) responded promptly but relapsed each time as soon as the treatment stopped.

One (Group 3) showed no definite response.

The general condition of all the children improved during treatment, but there was no improvement in the heart signs in any. In all, fourteen courses of combined therapy were given. The erythrocyte sedimentation rate became normal within 1 week in five, 2 weeks in three, 3 weeks in five, and in 4 weeks in one. Thus in all fourteen courses the erythrocyte sedimentation rate became normal within 4 weeks.

The erythrocyte sedimentation rate remained normal for three consecutive weekly readings in nine of the fourteen courses. In one the data were inadequate, while in the other four the erythrocyte sedimentation rate was never normal for as much as 3 weeks.

TABLE

RESPONSE OF SIX CASES OF CHRONIC RELAPSING RHEUMATIC FEVER TO CORTISONE AND SALICYLATES

\begin{tabular}{|c|c|c|c|c|c|c|c|c|}
\hline \multirow{2}{*}{ Group } & \multirow{2}{*}{$\begin{array}{c}\text { Case } \\
\text { No. }\end{array}$} & \multirow{2}{*}{$\begin{array}{l}\text { Age on } \\
\text { Admis- } \\
\text { sion } \\
\text { (yrs) }\end{array}$} & \multirow{2}{*}{ Therapy } & \multirow{2}{*}{$\begin{array}{l}\text { No. of Days before } \\
\text { E.S.R. first became } \\
\text { Normal }\end{array}$} & \multirow{2}{*}{$\begin{array}{c}\text { No. of Days before } \\
\text { First of Three } \\
\text { Consecutive Normal } \\
\text { E.S.R.s }\end{array}$} & \multicolumn{2}{|c|}{ Heart Sounds } & \multirow{2}{*}{ Rebound } \\
\hline & & & & & & Before & After & \\
\hline \multirow{3}{*}{1} & 1 & 11 & C.L.S.* & 7 & 7 & $\begin{array}{l}\text { Double mitral, } \\
\text { aortic } \\
\text { regurgitation }\end{array}$ & No change & + \\
\hline & 2 & 9 & $\begin{array}{l}\text { C.L.S. (1) } \dagger \\
\text { C.L.S. (2) }\end{array}$ & $\begin{array}{r}21 \\
7\end{array}$ & $\begin{array}{c}\text { Not estimated } \\
7\end{array}$ & $\begin{array}{l}\text { Double mitral } \\
\text { Apical systolic } \\
\text { Grade } 4\end{array}$ & $\begin{array}{l}\text { Apical systolic } \\
\text { Grade } 4 \\
\text { Apical systolic } \\
\text { Grade } 4\end{array}$ & $\begin{array}{c}+ \\
+ \text { (when dose } \\
\text { became low) }\end{array}$ \\
\hline & 3 & 9 & C.L.S. & 7 & 7 & $\begin{array}{l}\text { Apical systolic } \\
\text { Grade } 3\end{array}$ & $\begin{array}{l}\text { Apical systolic } \\
\text { Grade } 3\end{array}$ & \\
\hline \multirow[t]{2}{*}{2} & 4 & 11 & $\begin{array}{l}\text { C.H.S. (1) }{ }^{\dagger} \\
\text { C.H.S. (2) } \\
\text { C.L.S. (3) } \\
\text { C.L.S. (4) } \\
\text { C.L.S. (5) }\end{array}$ & $\begin{array}{r}12 \\
18 \\
7 \\
28 \\
14\end{array}$ & $\begin{array}{r}33 \\
18 \\
7 \\
28 \\
42\end{array}$ & $\begin{array}{l}\text { Double mitral, } \\
\text { aortic } \\
\text { regurgitation }\end{array}$ & No change & \\
\hline & 5 & 13 & $\begin{array}{l}\text { C.H.S. (1) } \\
\text { C.H.S. (2) } \\
\text { C.L.S. (3) } \\
\text { C.H.S. (4) }\end{array}$ & $\begin{array}{l}21 \\
21 \\
21\end{array}$ & $\frac{21}{-}$ & $\begin{array}{l}\text { Double mitral, } \\
\text { aortic } \\
\text { regurgitation }\end{array}$ & No change & \\
\hline 3 & 6 & 13 & C.L.S. & 14 & - & Double lesion & No change & \\
\hline
\end{tabular}

* Cortisone with salicylates in low dosage.

+ This course was given in another hospital.

$\ddagger$ Cortisone with salicylates in high dosage. 


\section{Discussion}

There is no doubt that combined cortisone and salicylate therapy improved the general health of these children. We could hardly expect longexisting cardiac lesions to regress under treatment, and in fact, no such improvement occurred. In spite of the prolonged rheumatic activity in these patients, however, there was no deterioration in the state of the heart in any case.

The response to treatment, as judged by the erythrocyte sedimentation rate, was not as uniformly satisfactory as in children treated in their first attack, though the initial response was satisfactory in five of the six children. The marked tendency to relapse was disappointing. It may be that these relapses occurred because the disease was so well established in these chronic cases that therapy could only be suppressive and not curative. This would indicate the desirability of early treatment of children with rheumatic fever. It may be that we were dealing with a group of children with a type of disease that is naturally recurring and which has been termed polycyclic. This tendency to relapse in chronic cases may indicate that combined treatment should be continued for much longer periods than is necessary in children in their initial attacks treated early.

Our experience with this small group of cases leads us to suggest that children with long-lasting, smouldering rheumatic fever should have the benefit of combined therapy, for the response in some is likely to be good. Further investigation is required to determine the optimum duration of such treatment.

\section{Summary}

We have described the response to combined treatment with hormones and salicylates of six children with relapsing rheumatic carditis and prolonged rheumatic activity.

Altogether fourteen courses of treatment were given. Three children responded promptly, and did not relapse. Two children responded well but relapsed several times as soon as treatment was discontinued. In one child the response, as measured by the erythrocyte sedimentation rate, was doubtful, and she developed haematemesis as a result of treatment.
It is suggested that combined therapy is a useful method of treatment in children with smouldering rheumatic carditis, but that the duration of treatment may have to be prolonged.

We wish to thank the following physicians who kindly transferred cases to our care: Dr. A. C. Blandy (Nottingham), Dr. L. A. Hawkins (Doncaster), Dr. J. M. RiceOxley (Worksop), Dr. W. Twort (Nottingham), and Dr. T. Wright (Lincoln).

We also thank Miss A. E. Starr, Matron of the Ash House Hospital School, and her nursing staff, who cared so well for the children during their long hospital stay.

\section{REFERENCES}

Holt K. S., Illingworth, R. S., Lorber, J., Rendle-Short. J., and Gibson, W. M. (1954). Lancet, 2, 1144.

Illingworth, R. S., Lorber, J., Holt, K. S., Rendle-Short, J., Jowett, G. H., and Gibson, W. (1957). Lancet, 2, 653.

Lorber, J. (1957). Brit. med. J., 2, 749.

\section{La cortisone et les salicylates dans la cardite} rhumatismale récidivante chronique

\section{RÉSUMÉ}

On décrit la réponse à un traitement combiné, hormonal et salicylé, de six enfants atteints de cardite rhumatismale récidivante et de polyarthrite évolutive.

En tout on donna quatorze traitements complets Trois enfants réagirent rapidement, sans rechute. Deuxô enfants réagirent bien, mais eurent plusieurs rechutes? chaque fois que le traitement fut interrompu. Che une enfant la réaction, jugée par la vitesse de sédimentation globulaire, fut douteuse et le traitement fut suivi d'une hématémèse.

On suggère que la thérapie combinée est utile chez des enfants atteints de cardite rhumatismale latente, bien que la prolongation du traitement pourrait être nécessaire.

\section{La cortisona y los salicilatos en la carditis reumática recurrente crónica}

\section{Sumario}

Se describe la respuesta a un tratamiento combinado, con hormonas y salicilatos, de seis niños con carditis reumática recurrente y con poliartritis evolutiva.

Se dió un total de catorce tratamientos completos. Tres enfermos recobraron rapidamente, sin recaída. Dos niños respondieron bien, pero tuvieron recaídas al interrumpir el tratamiento. En una niña la respuesta, a juzgar por la velocidad de sedimentación globular, fué dudosa y el tratamiento fué seguido de una hematemesis.

Se sugiere que la terapia combinada es útil en niños con carditis reumática latente, aunque se pueda necesitar una prolongación del tratamiento. 